\title{
Deadly Doves: Liberal Nationalism and the Democratic Peace in the Soviet Successor States
}

\author{
Bear F. Braumoeller \\ University of Michigan
}

\begin{abstract}
This article's purpose is to assess the arguments of democratic peace scholars as they apply to the states of the former Soviet Union. The claim that liberalism is associated with nonviolent means of conflict resolution, in particular, is questionable in the case of newly independent states, in which liberalism bears a closer resemblance to nineteenth-century European liberal nationalism than it does to the universalist liberalism envisioned by theories of the democratic peace. I argue that this nonuniversalist form of liberalism is in fact widespread among the Soviet successor states and that, as a result, liberalism's implications for peace are not nearly as benign as had previously been believed. In other regards, however, the attitudes of elites, the mass public, and liberals are in fact fairly consistent with those posited by democratic peace theory, though relative elite bellicosity declines as the policy-making arena broadens. A democratic peace in the region is therefore viable but particularly vulnerable to national issues, as well as to the effects of concentration of political power in the hands of a narrow group of elites.
\end{abstract}

The goal of this article is to assess whether the underlying assumptions about the attitudes of elites and masses in the democratic peace literature are applicable to the Soviet successor states. I argue that the literature on the democratic peace has failed to appreciate one very significant fact: liberalism as a belief system is not monolithic, and the form it takes and the context in which it arises determine whether the spread of liberal ideas will cause peace among liberal states or create opportunities for more conflict. At least as far as beliefs about the legitimacy of the use of force are concerned, the type of liberalism which has arisen in the Soviet successor states is more likely to do the latter than the former.

Given the importance which the United States has placed on relations with Russia and the former Soviet republics and the potential for conflict which they represent, ${ }^{1}$ the answer to this question is critical. Any region of the world in which the number of irredentist claims approaches, and by some counts surpasses, the number of sovereign states represents a grave danger to itself and to others. Russett, the most

Author's note: I am grateful to Molly Erickson, Matthew Evangelista, Ted Hopf, Paul Huth, Ellen Lust-Okar, Bob Pahre, Dan Reiter, David Rousseau, Anne Sartori, Stephen Tull, Joe Underhill-Cady, and especially William Zimmerman, as well as to the editors of International Studies Quarterly and three anonymous reviewers, for their comments and input on various drafts of this article.

1 The literature pertaining to this point is vast. Some of the more frequently cited examples are Mearsheimer (1990), Snyder (1990, 1994), and Van Evera (1990-91). 
prominent of democratic peace scholars, writes (1993:135-8) that the road to peace lies in democratization and that the West should therefore work to promote it. Layne (1994), on the other hand, suggests that the evidence for the democratic peace is not strong enough to warrant the conclusion that the possibility of inculcating democracy in Eastern Europe is worth the risk of subsequent regional entanglement. The question of whether or not liberalism, shared democracy, and/or institutional constraints suffice to ensure (or at least strongly promote) peace among these states is a critical one for the West as it faces difficult decisions regarding which regional policies to pursue.

The current consensus seems to be that they will. Democratic peace theories have proliferated in recent international relations literature: ${ }^{2}$ starting with Dean Babst's 1964 article, elaborations have appeared in a handful of books, dozens of articles, and hundreds of seminar and conference papers. This attention has produced a wealth of findings. Large-N studies have demonstrated, convincingly and repeatedly, that democracies are not significantly less warlike in general than are other types of regimes, ${ }^{3}$ but that they are significantly less warlike when dealing with one another: there have been no wars between democracies, ${ }^{4}$ and even warlike behavior-use of military force, display of force, or threat of force-is conspicuous in its absence (Small and Singer, 1976; Doyle, 1983a, 1983b; Chan, 1984; Rummel, 1985; Maoz and Abdolali, 1989; Russett, 1993; Oneal, Oneal, Maoz, and Russett, 1996). ${ }^{5}$ These statements seem to apply to sub-state groups and, to a lesser extent, to the democratic states of antiquity as well (Ember, Ember, and Russett, 1992; Russett, 1993).

These findings have been critically examined, at the very least, by those who question the definitions of democracy which are used (Chan, 1984, 1993; Bueno de Mesquita and Lalman, 1992; Ray, 1993, 1995; Oren, 1995), those who question the definition or operationalization of war (Chan, 1984, 1993; Morgan and Campbell, 1991; Weede, 1992; Dixon, 1994), and those who suggest that elements which are not central to the idea of democracy itself might be responsible for the pacificity of democratic dyads (Gaubatz, 1991; Morgan and Campbell, 1991; Lake, 1992; Bremer, 1993). More recently, the democratic peace has been called into question by subjecting it to tests against realism (Layne, 1994) and by suggesting that it is a plausible result of random chance (Spiro, 1994; Farber and Gowa, 1995; see also Russett, 1995; Spiro, 1995). Despite, or perhaps because of, this intense scrutiny, the results still stand. ${ }^{6}$

\footnotetext{
${ }^{2}$ From the onset, I should note that the phrase "democratic peace theory" is hardly without its problems. There are in fact quite a few theories to explain this phenomenon, and many imply that liberalism is as important as democracy; I use this phrase for the sake of convenience.

${ }^{3}$ For a notable exception to this generalization see Rousseau, Gelpi, Reiter, and Huth (1996), which suggests that selection effects in the process which leads from peace to war mask a significant monadic relationship between democracy and the use of force (both initiation and highest level used).

4 Some borderline cases make it difficult to say with absolute certainty that democracies have never gone to war with one another. Ray $(1993,1995)$ constitutes an outstanding examination of most of these cases.

${ }^{5}$ One interesting but relatively unexplored result found in Maoz and Abdolali (1989:23) is that autocratic states are less likely to initiate conflict with one another than are states in other types of dyads. Morgan and Campbell (1991) suggest that this relationship is due to the fact that autocracies and democracies face more leadership constraint than do "anocracies," or relatively incoherent states. Another interesting possibility was raised by Kissinger (1966), who suggested that similar administrative structures and similar formative experiences among leadership groups will promote greater understanding and will remove many of the sources of diplomatic friction that lead to war. Hermann and Kegley (1995) elaborate a similar position, discussing the democratic peace from the point of view of social identity theory. The latter two positions suggest that like states—not just democratic states—should be more pacifistic when dealing with one another.

${ }^{6}$ On this point, as should be apparent, informed opinion disagrees, often vehemently. My own position as of this writing is that the large- $\mathrm{N}$ critiques offered so far have yet to muster results sufficient to warrant the rejection of previous findings. See Russett (1995) for a defense of this position.
} 
Most explanations of the democratic peace phenomenon focus either on the constraint engendered by the domestic political structures of democratic states or on the impact of the liberal norms associated with democracies as sources of peace (Morgan, 1993:200). ${ }^{7}$ Structuralists believe that the nature of the democratic political system itself is responsible for the democratic peace. Leaders are constrained from going to war by the domestic political system, not by ideology. Because leaders of democratic states can only remain in power by following the mandate of the vox populi —or at least by not disregarding it—-those leaders will not hazard the costs of going to war without the consent of the people (Morgan and Campbell, 1991; Kiser, Drass, and Brustein, 1995). Moreover, leaders of democratic states are aware of one another's constraints and, therefore, have no reason to fear attack from other democracies (Bueno de Mesquita and Lalman, 1992). Security, bred of mutual domestic disincentives, leads to peace. ${ }^{8}$

Proponents of the normative school, on the other hand, maintain that the normative foundations of liberalism, when applied to policymaking in the international realm, are conducive to peace. The fact that democracies do not fight one another is explained by the fact that democracy is strongly associated with liberalism, ${ }^{9}$ which in turn gives rise to mutual respect and beliefs in both autonomy and freedom from foreign intervention. These beliefs result in peace among states that share them (Doyle, 1983b). ${ }^{10}$

I argue that, in the states of the former Soviet Union, the logic which underpins normative theories of the democratic peace is unlikely to hold. The parallel institutional and ethnic cleavages of the old regime created an incentive, once glasnost was under way, to voice secessionist claims in both political and national terms. At the same time, the struggle for national self-determination which resulted in the Union's dissolution created tension between two of liberalism's fundamental tenets: peaceful resolution of conflicts and autonomy. The result has been the rise of a nonuniversalist form of liberalism—specifically, liberal nationalism ${ }^{11}$ — which explicitly values the latter over the former. The existence of a nonuniversalist liberalism makes it possible to speak of the freedom of the individual, not from the state, but from a different group of individuals. Conflict therefore manifests itself, not between the individual and the state, but between groups-a development that may be more, not less, likely to lead to international conflict, especially if the geographical boundaries of the group (in this case, the nation) differ from those of

\footnotetext{
7 The distinction between the independent variables, liberalism and structural constraint, is of cardinal importance. Neither is synonymous with democracy, though both are associated with it. Nondemocracies can be subject to constraint (Morgan and Campbell, 1991), and democracies vary in the degree to which their citizens collectively espouse liberal norms (Lilla, 1994). Therefore, oddly enough, it may be inaccurate and misleading to attempt to divine the sources of the democratic peace by measuring democracy. The primary implication of this observation is that the scholarly debate is miscast: the positive heuristic of the democratic peace research program-that is, in Lakatos's words, the "methodological rules" which tell us "what paths to pursue" (Lakatos, 1970:132)—is poorly aimed, has been for some time, and will continue to be as long as theories fail to take into account the distinctions between democracy, liberalism, and constraint.

8 The most parsimonious variants of these explanations are monadic - that is, liberalism breeds pacifism and republicanism breeds constraint, regardless of the nature of a state's potential opponent. Such explanations are hard-pressed, however, to explain the fact that democracies are no less warlike vis-à-vis undemocratic states than are any other types of states. Recently Bueno de Mesquita and Lalman (1992) have constructed a signaling game which demonstrates that dyadic restraint is a plausible product of monadic structural constraint, and Ray (1995:30-1) has pointed out that their argument works equally well for monadic normative constraint.

${ }^{9}$ More specifically, democracy both promotes liberalism and relies on it as a source of legitimation; though it may be difficult to say that one "causes" the other, they have a tendency to coexist symbiotically.

${ }^{10}$ This review is necessarily cursory; for a more elaborate index to recent studies see Hermann and Kegley (1995:513).

${ }^{11}$ My treatment of this phenomenon is largely historical rather than philosophical. Readers interested in more detailed discussions of the theoretical (in)compatibilities of liberalism and nationalism should see Tamir (1993), as well as the many thoughtful and thought-provoking reviews it has prompted, especially Levinson (1995).
} 
the state. Liberal nationalism is centered on the idea of national self-determination; its adherents- "deadly doves" - are both very liberal and very willing to use force to achieve their goals. ${ }^{12}$

The struggle for independence in Ukraine, as in most non-Russian republics, during the slow disintegration of the Soviet Union followed this pattern: the desire for national independence was one that appealed to both liberalism and nationalism, and the result was a fusion of the two ideologies. In Russia, on the other hand, liberalism and nationalism have never coexisted peacefully. From the time of Peter the Great, liberalism has been viewed by Russian nationalists as an imported European idea, one that is unsuitable for Russia. The dissolution of the Soviet Union did not bring about the same commonality of purpose between liberalism and nationalism in Russia that it did in other former republics, simply because Russia's independence was never at issue. The main question as the Soviet state disintegrated was not whether Russia would be independent but rather whether or not the political entities around it would remain part of its territory.

It is therefore reasonable to expect that democratic peace theories' predictions regarding the attitudes of liberals in the Soviet successor states will be incorrect in one critical area: the reluctance of liberals to use force. It is also reasonable to expect this effect to be strongest in those republics that fought earliest and hardest for independence.

First, I will briefly discuss existing theories of the democratic peace and derive hypotheses about the attitudes that should be found in elites and the citizenry if those theories are to be believed. Next, I will elaborate upon the above discussion of the relationship of liberalism to nationalism in Russia and Ukraine and of the effects of the Soviet system on that relationship. Based on this discussion I will then derive hypotheses regarding the attitudes of liberals versus illiberals, and elites versus the mass public, in both countries. Following this section, I will test all of the hypotheses, using data from surveys carried out in Russia and Ukraine between 1993 and 1995. Finally, in order to gauge the generalizability of the results regarding liberalism and nationalism, I will examine data from a 1990 survey of nine Soviet republics and assess their implications regarding the relationship of the two to one another.

\section{Theories and Hypotheses of the Democratic Peace}

In the following discussion I will focus on two necessary events in the process that leads to war initiation in democracies: first, a perception of conflict must exist, and second, force must be decided on as the appropriate means of resolving that conflict. The reason for focusing on these events is simple: they are the two points at which, by most accounts, structural and normative factors are supposed to prevent war. ${ }^{13}$

\footnotetext{
12 I should note that the implications of this argument for the Soviet successor states have some important points of contact with those put forth by Mansfield and Snyder (1995). The authors point out that democratizing states are more, not less, likely to go to war with other states. They attribute this fact to a combination of elite coalition politics, which gives elites the incentive to mobilize the citizenry with nationalistic rhetoric, and imperfect institutions (pp. 7, 22), which permit the manipulation and misinformation necessary for such a strategy to succeed. I argue, on the other hand, that liberalism in newly independent states is of a sort that is not particularly pacifistic, and may even be belligerent, due to the circumstances surrounding its conception. When applied to the Soviet successor states, Mansfield and Snyder's argument suggests that the democratic peace may not hold because one of its preconditions-stable, functioning institutions-is absent. My critique, in a way, is more damning: if the argument is correct, the newly independent states may be more war-prone because the preconditions stipulated by democratic peace theorists are present.

${ }^{13}$ Hence my use of the word "necessary"; in the democratic-peace account, the detour on the road to war occurs at one of these two points, so if all instances of peace between democracies are to be attributed to the variables highlighted by democratic peace scholars, it must be the case that all potential wars between democracies must pass through these two stages.
} 
Therefore, if either shared liberalism or shared structural constraint is responsible for the democratic peace, it should be the case that they result in either a lowered perception of conflict between states or a compulsion to favor nonviolent solutions to conflicts once they arise. ${ }^{14}$

\section{Structural Theories}

Structural theories generally posit that the domestic political structure of democratic states is configured such that leaders can be rendered unable to involve their countries in war due to the prohibitively high political costs of doing so. ${ }^{15}$ Democracies can avoid war with one another because they are aware of one another's constraints: decision makers in each democratic country know that they need not fear attack from the others. ${ }^{16}$

Arguments to this effect are based on some form of mechanism for constraint which operates in democracies. They differ in that they describe diverse ways in which such mechanisms are set in motion. For Kant, constraint is based on the assumption that costs will be higher for the citizenry than for the elite (Kant, 1957). For Montesquieu, Schumpeter, and others, the likely economic costs of war, which citizens are unwilling to bear, bias leaders' decision calculus toward peace (Montesquieu, 1900; Schumpeter, 1955). Bueno de Mesquita and Lalman (1992:153-4, 297-8) proceed from somewhat different assumptions-namely, that domestic political costs are a function of a state's probability of success in war and its valuation of the status quo.

In any case, the common foundation of structural arguments is the proposition that democracies do not fight because leaders are constrained from doing so by domestic political costs, regardless of the origins of those costs. ${ }^{17}$

\section{HYPOTHESES}

Constraint is very difficult to measure. Using a survey, it might be possible to gauge the extent to which leaders believe themselves (or one another) to be constrained, but the degree to which leaders perceive constraint is likely to be influenced by recollections of a few salient events. As recent events tend to be more salient, and the surveys took more than a month to execute, it is likely that earlier responses would differ from later responses because they would be based on different events. The results would very likely be biased in unpredictable ways and therefore be unusable.

It is possible, however, to test other logical implications of structural theories. All of them imply that, in one way or another, leaders are more prone to use force than are the people. Indeed, if leaders are held in check by political costs generated by the public, this must be the case. ${ }^{18}$ If it were not-that is, if the public and their

14 As both perception of hostile relations and the decision to use force are necessary for a democratic state to initiate a war, showing that liberal norms or structural constraint impedes either of these processes would be adequate to provide support for democratic peace theories.

15 As Morgan and Campbell (1991) point out, such constraint is not unique to democratic states-any domestic political regime that limits the power of the executive, or in which the executive faces a competitive selection process, is to some degree constrained. Despite the fact that all constrained states are not democratic, however, all democratic states are constrained.

${ }^{16}$ For elaboration of this point see Bueno de Mesquita and Lalman (1992:ch. 5) and Russett (1993:40).

17 It could be argued that Lake (1992) is an exception to this generalization. He suggests that democracies are less able to collect rents than are their autocratic counterparts and as a result will be less expansionist. Their constraint therefore arises, not from costs, but from lack of benefits.

18 Note that I do not assume, or claim, that such institutional constraint functions in these states. Both the impetus to constrain and the mechanisms for constraint are necessary for constraint to occur; even if I can demonstrate that the impetus to constrain exists, institutional factors will determine whether or not it will be realized. 
leaders were possessed of equally bellicose proclivities—why would any costs ever be imposed on leaders for the use of force?

Again, this study will focus on two critical junctures on the path from peace to war: the perception of conflict between two states, and the decision to use force to resolve that conflict. Therefore, if the structural argument can be supported, at least one of the following hypotheses should be confirmed:

H1: Leaders perceive foreign relations to be more conflictual than do citizens.

H2: Leaders are more likely than citizens to advocate the use of force to resolve conflicts.

\section{Normative Theories}

The general normative argument is that some of the characteristics of states that create in them the desire to go to war are absent in relations among democracies. This lack of impetus stems from the nature of the shared liberal ideology which legitimates such states - specifically, from the moral and political underpinnings of that ideology. ${ }^{19}$ This pacifism does not extend to undemocratic states, whose lack of legitimacy and propensity to act in a manner antagonistic to liberalism introduce the possibility of conflict. Therefore, according to this view, liberalism and the belief that a potential opponent is democratic are both necessary, but only jointly sufficient, to ensure peace among democracies.

The proposed linkages between liberalism and peace are numerous and complex. First, de Tocqueville suggests that liberalism's emphasis on individual freedoms tends to undermine nonegalitarian social divisions and hierarchies, resulting in greater perceptions of equality among peoples. ${ }^{20}$ From these perceptions will arise a fundamental empathy, and empathy brings with it lack of conflict: “. . . the mildness of manners, the gentleness of heart, those tendencies to pity which are produced by the equality of conditions ... - -all these causes concur to quench the military spirit" (Tocqueville, 1873:324).

Second, due to this notion of fundamental equality, liberal political culture places an emphasis on the behavioral norms of exchange and cooperation rather than coercion. The division of power within a party system, for example, implies that outcomes must be negotiated rather than mandated (Rummel, 1985:420-1). Thus, a liberal political order inculcates norms of reciprocity in its citizenry. As Leng (1993) has shown, in fact, liberal democracies are more likely than other states to utilize reciprocal, or tit-for-tat, bargaining strategies in order to induce cooperation.

As a result, liberal states de-legitimate violence as a means of achieving political objectives (Chan, 1984, 1993; Rummel, 1985). As Nincic succinctly puts it, "The values on which liberal democracy is founded and the practice of negotiating differences that is the hallmark of its political culture do not lead to easy belief in the virtues of military coercion" (Nincic, 1992:9). Competition is legitimate and

${ }^{19}$ Since the publication of Doyle's (1983a, 1983b) work, which specifically pointed to liberal norms as the cause of the peace between liberal states, the tendency has been for scholars to switch to an emphasis on democratic, rather than liberal, norms (see, e.g., Russett, 1993:30-8). I have chosen to examine liberal, rather than democratic, norms because doing so seems to me to be more true to the original formulations of the normative school. In any event, as I will argue in the section on operationalizations, belief in representative government is one element of liberal norms.

${ }^{20}$ It is interesting to note, as does Sartori (1987:359, 383-6), that the individualistic essence of liberalism and the egalitarian nature of democracy can pull in different directions-all the more reason to keep in mind the distinction between liberalism and democracy, as what follows from the former need not follow from the latter. For example, European liberals in the first half of the nineteenth century stood for equality in its legal sense alone, and therefore opposed such democratic notions as universal manhood suffrage. For a spirited argument that liberty and democracy are in fact incompatible see Guizot (1852:72-3, 347-9). 
necessary, but bounded (Dixon, 1994:15-6)—the institutions of government are utilized for the nonviolent resolution of competing claims.

Liberal pacifism is by no means absolute, however. The tolerance which lies at the heart of liberal ideals cannot be universal; nowhere in the classical liberal tradition does one find a defense of arsonists or murderers, for example. Liberalism generally advocates a conditional freedom-that is, the freedom (of an individual or a state) to act in virtually any manner, as long as no harm is done to others (Mendus, 1989:118-9). In short, "Every society fears and excludes some 'wrong' freedoms" (Spitz, 1982:15). Accordingly, the peace engendered by empathy and reciprocity extends only to those states that abide by liberal principles: in so doing, they avoid behavior that liberal states consider "just cause" for war.

\section{HYPOTHESES}

The best way to test the propositions of the liberal-norms school is to examine the attitudinal dispositions of liberals versus illiberals within a society. ${ }^{21}$ By virtue of their emphasis on empathy and reciprocity, adherents to a liberal ideology should perceive less conflict with other states if they believe those other states to be democratic. Because of their predilection for nonviolent means of conflict resolution, they should also be less likely to advocate the use of force in general. ${ }^{22}$ If these statements are true, the following hypotheses should be confirmed:

H3: Individuals who are themselves liberals, and who believe another country to be democratic, will perceive less conflict with that country than would otherwise be the case.

H4a: Liberals are less likely than illiberals to advocate the use of force to resolve conflicts.

\section{Liberal Nationalism}

Most modern portrayals of nationalism suggest that liberalism and nationalism are flatly contradictory in that the former implies, and the latter precludes, universal recognition of individual rights and autonomy. This viewpoint has led to an "either-or"-ism in the minds of many prominent thinkers, ${ }^{23}$ as well as considerable disillusionment with nationalism among scholars of liberalism (Judt, 1994) and of international relations (Snyder, 1993).

Nevertheless, Fukuyama (1992), who argues that liberalism and nationalism are contradictory, concedes that an accommodation between the two is possible if nationalism becomes tolerant. (The example of tolerant nationalism he chooses, incidentally, is post-Soviet Ukraine.) Moreover, critics of liberal theory (Schmitt,

${ }^{21}$ My use of the somewhat awkward word "illiberal" rather than "conservative" is due to the fact that conservatism consists of more than the absence of liberalism. Illiberals are not automatically adherents to, say, Burkean conservatism, with its emphasis on religion and circumstantial morality.

${ }^{22}$ Complete dyadic explanations specify that peace will arise only if both sides exhibit an aversion to violence; otherwise the more doveish side may be tempted to preempt, knowing its violent opponent's nature. It is still the case, however, that liberal states - and by extension liberals—should exhibit an aversion to violence in general in the first place; otherwise, their democratic partners could find no reassurance in their norms. It is this general perception, that the use of force in resolving conflicts is illegitimate, that I attempt to gauge here.

${ }^{23}$ For example, Smith (1991:144) writes that "the anti-communist movements in Eastern Europe in 1989 were at first treated as western-style movements of political and economic liberalism, until it was realized how powerful were the nationalist dimensions of popular mobilization"; and Kaiser (1994:397) notes, "The recent events in Georgia also provide strong evidence that nationalism rather than democracy was the mobilizing force behind the demise of the USSR." 
1985:11; Hochschild, 1986:398) have suggested that liberalism is nowhere truly universal, and that the nation provides a common delimiter for its scope. ${ }^{24}$ Tamir (1993:121) notes that, "Since liberalism cannot provide a theory of demarcation, it has adopted for this purpose the national ideal of self-determination." Even John Stuart Mill wrote that "[f]ree institutions are next to impossible in a country made up of different nationalities" due to the heterogeneity of the populace and the conflict that would inevitably ensue (Mill, 1958:232).

An examination of the history of nationalism (see especially Hayes, 1931; Kohn, 1944; Shafer, 1972; Anderson, 1991; Smith, 1991; Hobsbawm, 1992; Nodia, 1992) suggests that, more than simply exhibiting some degree of compatibility, liberalism and nationalism have often been intimately linked to one another. Liberal nationalism, though it had already established firm roots in England prior to the Revolution, made its continental début as a reaction to the retrograde tendencies of traditional nationalism as well as to the frank denial of individualism embodied by Jacobin nationalism. ${ }^{25}$ Its primary emphasis was autonomy, the right of individuals to self-government-a goal upon which liberalism and nationalism were in ready agreement.

The two ideas found a common home in the revolutionary movements of the first two thirds of the nineteenth century largely because the boundaries of nations were only very rarely the same as the boundaries of states. This brings up a critical point: because its goal-indeed, its raison d'être-was national self-determination, and because the majority of nations were subject to alien rule or rules, liberal nationalism had either to accept an extremely undesirable status quo or to abandon liberalism's principled objection to the use of force.

Here, then, was the tragedy of liberal nationalism, not unlike that of the earlier Jacobin nationalism. Its logic and its fine intentions were not sufficient of themselves to insure its triumph. It needs must grasp the sword and slay its adversaries.

The sword, therefore, it repeatedly grasped, and its adversaries it slaughtered in vast numbers. Revolt followed revolt, and war followed war. Under liberal auspices occurred the terrible rebellions of "enslaved" Greeks and Yugoslavs against the Ottoman Empire and of "oppressed" Latin Americans against Spain; the riots of 1820 in Italy and Spain; the widespread insurrections of 1830 in France, Belgium, Germany, and Italy; the even more widespread and deadly insurrections of 1848 in France, Germany, Italy, Austria, Switzerland, and Ireland; the Polish uprisings of 1831 and 1863; the Crimean War of 1854-1856; the wars of Italian unification in 1848-1849, 1859-1860, 1866, and 1870; the wars of German unification in 1848-1849, 1864, 1866, and 1870-1871; and the mighty struggle of 1861-1865 in the United States for the preservation of a national union and the emancipation of an enslaved race. (Hayes, 1931:161-2)

This acceptance of violence is the source of Best's (1988:11) comment: "The [French] Revolution's goodwill towards humankind blew from the barrels of its guns

\footnotetext{
${ }^{24}$ Schmitt (1985:9) makes this point well: "Every actual democracy rests on the principle that not only are equals equal but unequals will not be treated equally. . . . In the democracy of English sects during the seventeenth century equality was based on a consensus of religious convictions. Since the nineteenth century it has existed above all in membership in a particular nation, in national homogeneity." (Emphasis added.)

25 The typology follows that of Hayes (1931); though others are equally valid, this one focuses most usefully on the period surrounding the emergence of liberal nationalism.
} 
as well as from the mouths of its orators." The new ideology brought with it new kinds of conflict, wars for sovereignty among states and sub-state groups whose conception of legitimacy and of the nation itself differed (Waltz, 1959:107-9; Howard, 1978; Hoffmann, 1995:164). ${ }^{26}$

European liberal nationalism, by most accounts, was gradually subsumed by integral nationalism, the variety best known to (and least loved by) twentieth-century scholars. ${ }^{27}$ The prevalence of integral nationalism in the twentieth century often creates the mistaken impression that all nationalism is integral, that liberal nationalism died in August of 1914 in Sarajevo (if not in January of 1871 at Versailles). Abundant evidence indicates that this is not the case. Hayes (1931:165) notes that, although liberal nationalism is for the most part a phenomenon found in oppressed or subject nationalities, "liberal nationalism is still an active force" even in post-independence nations. It is nevertheless true that liberal nationalism has found its home for the most part in nations that are not yet states or that have recently achieved statehood: locations as dissimilar as post-colonial Africa (Neuberger, 1986:17, 78), modern Quebec (Stark, 1995), and the successor states to the Soviet Union.

\section{The Soviet Context}

Ironically, the entity most responsible for the appearance of liberal nationalism in the Soviet successor states following the collapse of the Soviet Union may have been the Soviet state itself. Faced with the problem of governing people of over 100 nationalities, the Soviet state responded by organizing itself as a federal state and dividing its political subunits along national lines. Fifteen nations were given full republics of their own, while smaller nationalities were often given an autonomous republic, region (oblast), or area (okrug).

When the question of independence arose, these national-political divisions became fault lines: the largest national groups had ready-made state structures and authority arrangements which greatly facilitated the organization and execution of independence movements (Breuilly, 1993:346-7). At the same time, the conflicts that grew out of the state's dissolution spurred the growth of nationalist sentiment. To the extent that political and ethnic boundaries were aligned in the non-Russian republics, liberalism and nationalism found common cause in the struggle for independence from Russia. ${ }^{28}$ Liberals were among those most ready to die-and, if necessary, kill-for their nation's independence. In Russia, on the other hand, the goal of the use of force would have been to quash rather than to ensure autonomy - a goal liberals found distasteful at best but which nationalists actively promoted.

\section{Liberalism in Ukraine}

One of the best examples of the role of Soviet federalism in the facilitation of liberal nationalism, in fact, is Ukraine. Prior to World War II, Ukrainians were divided

${ }^{26}$ It is worth noting that the use of force was generally principled-as Willis (1928:133) wrote of British liberal opinion during World War I, "Stern fighting would be necessary, but if the sword were in one hand, the Bible, or at least J. S. Mill, should be in the other."

27 There is considerable merit to the idea that the latter derived much of its form from the realization of the former. Liberal nationalism's emphasis on the unity of the nation and acceptance of the use of force, crucial in struggles for national independence, often manifested themselves in chauvinism, militarism, intolerance, and in the extreme expansionism once independence had been achieved (Hayes, 1931:166, 225-8). Germany found that, although liberalism can be conducive to nationalism, nationalism need not be conducive to liberalism; the failure of German liberalism following the unification of the country is particularly illustrative of this process (Sheehan, 1978; Schwan, 1987).

${ }^{28}$ For a cogent analysis of the relationship between conflict and identity see Hopf (1996). 
among Soviet Ukraine, Poland, and Hungary; following the Soviet victory Stalin annexed the latter territories to Ukraine, bringing all Ukrainians together within the same state. For this reason, Subtelny (1994a:188) concludes that "it is extremely doubtful whether Ukrainian nationalist forces could have ever been as effective in maintaining and expanding Ukraine's borders as was the Soviet regime."

That these national movements incorporated substantial elements of liberalism is difficult to deny. ${ }^{29}$ The Draft Program of the People's Movement of Ukraine for Perestroika (Rukh) of February 1989 contains a strong emphasis on individual freedoms, both positive and negative, and a condemnation of ethnic exclusivism. It also advocates the inclusion of national minorities in Ukrainian political life. Less than a year and a half after this Program was made public, the Ukrainian Supreme Soviet issued a declaration of sovereignty, using language very similar to Rukh's (see Furtado and Chandler, 1992). In subsequent years Rukh has taken considerable pains to distance itself from more virulent ethno-nationalists (Subtelny, 1994a:190).

Nor is Ukraine the only example of liberal nationalism in the post-Soviet sphere:

The national movements in the three Baltic states, the Ukraine and Moldavia were not monolithic, but the largest group in each republic constituted itself as a "popular front." Two things strike one immediately about these fronts. They are democratic both in their aspirations and in their operations, and they are not ethnically exclusivist. In each republic members of ethnic minorities are welcomed by, and participate in, the fronts. These characteristics set off the Soviet European fronts from some of the national movements and nationalist parties that have emerged in Eastern Europe, as well as perhaps from parallel movements in the Caucasus and Central Asia, and certainly from some of the more radical Russian nationalist groups. (Gitelman, 1992:17)

In Ukraine, as in the non-Russian republics in general, the dissolution of the Soviet Union combined with preexisting national/institutional cleavages to provide strong incentives for independence. This objective appeals to both liberalism and nationalism; therefore, accommodation between the two was not difficult, and the pro-independence "national fronts" accommodated elements of both. As the next section demonstrates, this was not the case in Russia.

\section{Liberalism in Russia}

Liberalism and nationalism have been staunch adversaries in Russia since the Westernization that occurred under Peter I and Catherine II. Probably the earliest visible sign that liberalism was taking root as a viable alternative ideology to autocracy was the uprising of the Decembrists in 1825 (Riasanovsky, 1984:319-20). By 1830 the schism between Slavophiles and Westernizers which was to inspire much of nineteenth-century Russian art, literature, and politics had become apparent. Slavophilism, with its emphasis on the uniqueness of Russian history and glorifica-

29 This is not to say, of course, that all nationalism in Ukraine and the other Soviet successor states is liberal. In the case of Ukraine, the independence struggle in the years following the first World War began as a liberal nationalist endeavor but before long was overtaken by a particularly virulent form of integral nationalism, one that persisted in underground organizations in Ukraine for well over a decade (Subtelny, 1994b:441-4, 553-4). Nevertheless, as Armstrong (1990:14-5) notes, "There remained . . strong elements of liberal and democratic, as well as Christian, principles, even when the participants in the movement verbally rejected them. Formal learning, respect for established authority, individual decision, and popular choice were never completely absent from the real workings of even the most radical groups." 
tion of life on the mir, was quintessentially nationalistic, but it flourished specifically as a reaction against the encroachment of Western ideas (Kaiser, 1994:38). By the early 1900s, liberalism had become fairly widespread, so much so that the Constitutional Democrats (Kadets), formed in 1905, comprised large percentages of the first two Dumas. The liberalism of the Kadets, however, had little in common with that of mid nineteenth-century liberal nationalists like Mazzini: individual rights were seen as an end in themselves, rather than as a necessary component of national self-determination. In short, the Kadets already had their own country; they just wanted to improve it by establishing a constitutional regime (Salvadori, 1972; Riasanovsky, 1984).

Despite the ideological orthodoxy of the Soviet years, recent Russian politics have in many interesting ways mirrored the Slavophile-Westernizer split (Khasbulatov, 1993:57, 123; McFaul and Markov, 1993:13-4; Kaiser, 1994:39). Liberalism and nationalism have found themselves at cross-purposes: liberals' willingness to countenance self-determination flies in the face of nationalists' desire not to replace a political system which, despite its flaws, was largely of Russian design with a system based on those of Russia's Cold War adversaries (Hough and Fainsod, 1979:568-9).

Moreover, there has not been any strong impetus for liberalism and nationalism to join forces in order to "free" Russia. Russia, in that it was the heart of the old Soviet Union, was already its own country, the Union its empire. To nationalists, the liberation of Russia from Soviet rule meant the disintegration of that empire and the deterioration of Russia's international position, goals they found less than appealing (Breuilly, 1993:350). Accordingly, efforts to form "popular fronts" in the RSFSR, unlike those in other republics, fell through abruptly and often due to the inability of liberals and nationalists to agree on a program. By one account (Dunlop, 1983:76) there were at least six such attempts, all of which failed.

\section{HYPOTHESES}

If the liberalism which I have measured in Ukraine is in fact of the nationalist sort, there are some relatively straightforward predictions which should be borne out by the evidence. First of all, we should find that Ukrainian liberals, due to the circumstances surrounding the rise of liberalism in Ukraine, are more willing to use force than illiberals, though this is not necessarily true of liberals in Russia.

Secondly, we should find that liberals in Ukraine are more likely to associate themselves with nationalism than are illiberals, but that this relationship does not hold in Russia. This is the crucial test: much of the nationalism in the Soviet successor states is integral rather than liberal and is therefore of a form that pure liberals would certainly find unappealing, so conventional wisdom would suggest that the relationship between the two is likely to be negative, not positive.

Finally, we would expect liberals in Ukraine to evince a particular view of citizenship, stressing tolerance toward the views of ethnic minorities and permissive citizenship laws. How meaningful the results of this test are depends critically on the results of the second test. That liberals are tolerant and inclusivist would come as no surprise in and of itself, but the argument for liberal nationalism in Ukraine will be strengthened considerably if they are demonstrably nationalistic as well.

Therefore, if the liberalism measured in the Ukrainian survey is in fact of a nationalist variety, we should expect the following hypotheses to be borne out:

H4b: Liberals in Ukraine are more likely than illiberals to advocate the use of force to resolve conflicts, especially those involving Ukraine and Ukrainians.

H5: Liberals should identify themselves with nationalists in Ukraine but not in Russia. 
H6: Liberals in Ukraine should express inclusivist concepts of citizenship.

\section{Research Design}

\section{The Surveys}

Three surveys, designed at the Center for Political Studies (CPS) at the University of Michigan, are the primary sources of data for this study. The first is a mass/elite survey carried out in Russia in February and March 1993, the second is a nearly identical survey carried out in Ukraine in April 1994, and the third is a follow-up mass/elite survey carried out in Russia in October and November of 1995. 30 The first survey contains a small number of questions relevant to this project and in many ways was intended to gauge its feasibility. The results were so striking that further questions were included in the second and third surveys, with the goal of providing a more comprehensive test of a wider range of theories.

The composition of the surveys is as follows. The 1993 Russian mass survey is made up of 1,243 respondents, randomly selected from European Russia. ${ }^{31}$ The 1994 Ukrainian survey, in which no elites were interviewed, was conducted throughout Ukraine. The 1995 Russian mass survey is made up of 820 respondents, also drawn from European Russia. ${ }^{32}$ The 200 Russian elites surveyed in 1993 and the 180 surveyed in 1995 were selected because their positions occasioned considerable contact with foreign policy issues. They are divided among five occupations: the media, academics, economic elites (businesspeople and government officials), the military high command, and political elites (legislators and executives). ${ }^{33}$ Because of this study's focus on the difference between the people most directly responsible for decisions regarding war and peace-in short, leaders-and the mass public, only the latter two categories are used (unless otherwise noted). ${ }^{34}$

A fourth survey, carried out by Gibson and Duch (1990), is also used to assess hypotheses regarding liberalism and nationalism. This survey provides a particularly valuable glimpse of the values and beliefs of the citizens of the republics on the eve of the Union's dissolution. The survey covers nine republics; one, Estonia, had to be dropped because the number of valid responses was too small to permit analysis.

\section{Operationalization of Key Variables}

The hypotheses sketched above require that a total of seven variables be measured before they can be evaluated. Those seven are: leader/citizen status; liberalness; perceptions of hostility of other states; perceptions of the degree of democracy that characterizes other states; advocacy of the use of force; nationalist attitudes; and opinions about citizenship.

${ }^{30}$ All three surveys were carried out under the auspices of Professor William Zimmerman. Without his inclusion of relevant questions on the surveys, this study would not have been possible.

31 More precisely, "The 1,243 people interviewed were identified by a five stage sampling design with sampling units selected with a probability proportional to unit size in the first three stages. After that narrowing process, households and apartments served as sampling units drawn from address lists (interviewers prepare lists of households in small villages lacking a household register) and then persons were randomly selected from the identified households. The care with which the sample frame was constructed and the persons interviewed were selected, given the design, was far greater than in surveys undertaken in the ex-Soviet Union as recently as 1988-89" (Zimmerman and Stam, 1994:6-7).

32 The sample design differs from that of the 1993 survey in that very remote oblasts were eliminated from consideration. Although this alteration should result in certain changes in univariate distributions, there is little reason to believe that multivariate relationships will be systematically and significantly biased at this level of generalization.

33 The 1993 survey contains interviews with 40 individuals from each category. The 1995 survey contains interviews with 30 individuals from each category, as well as 30 individuals in an additional category of economic elites.

34 The implications of including all categories of elites are examined below. 
The first is fairly straightforward-the military and political elites who were interviewed in Russia are coded as leaders, ${ }^{35}$ other elites were dropped from the analysis in order not to bias the remaining population, and everyone else was coded as a citizen. ${ }^{36}$ The remaining operationalizations are somewhat more complex. (Exact question wordings can be found in the Appendix.)

In the post-Soviet political environment, the word "liberal" has taken on a bewildering variety of meanings. Simply asking whether or not someone considered him- or herself to be a liberal would not produce meaningful results. Therefore, respondents were asked questions designed to gauge how well they would fit the classical Western definition of a liberal, based on their beliefs along three dimensions: positive freedoms, negative freedoms, and the role of competition in government (Doyle, 1983b). These three dimensions were then incorporated into a simple additive index ${ }^{37}$ of liberal attitudes. ${ }^{38}$

In order to measure perceptions of democracy and hostility on the part of other countries, respondents were given a list of countries, asked whether the other country was more or less democratic than, or as democratic as, their own, ${ }^{39}$ and then asked to rank them on a five-point hostility scale ("very friendly" to "very hostile"). The other countries listed in the survey were China, the United States, Estonia, Poland, Germany, and Georgia; in addition, Ukrainians were asked about Russia and Russians were asked about Ukraine. The inclusion of a variety of countries in the questionnaire served to decrease the chances that the results were idiosyncratic and therefore to mitigate the "small-N" problem inherent in this approach. As liberalism and perceptions of democracy were hypothesized to be individually necessary but only jointly sufficient to bring about lessened perceptions of conflict, they were multiplied together to form an interaction term in that equation.

In the Ukrainian survey, advocacy of the use of force was assessed across a wide range of scenarios, including: defense of the country's territorial integrity; ${ }^{40}$ economic imperatives; defending the interests of countrymen abroad (both in the former Soviet Union and elsewhere); achieving national security; resolving other crises elsewhere; and getting the country out of its current crisis. Unfortunately, these questions were not asked in the 1993 Russian survey. In the 1995 Russian survey, however, five of the seven scenarios from the Ukrainian survey were repeated, while "achieving national security" and "resolving other crises elsewhere" were replaced with "defending the interests of the Russian state" and "defending the security of our friends abroad."

3580 people in the 1993 survey, and 60 in the 1995 survey.

36 No Ukrainian respondents were coded as elites.

37 The variables were also incorporated into a factor analysis, but the resulting factor correlated so highly with the additive index (e.g., 0.994 in the 1993 survey of Russia) that the latter was preferred for reasons of simplicity.

38 For the pioneering work utilizing this index of liberalism see Zimmerman (1994).

${ }^{39}$ Ukrainian respondents were also asked what democracy meant to them. As a check on the validity of the perceived democracy questions, I examined the marginal probabilities of responses to these questions. On some dimensions, the respondents evinced little understanding of democracy (the distribution of responses on the question of whether democracy involved state ownership of industry, for example, was practically uniform), but on the items Westerners most strongly associate with democracy (free elections, political parties, free speech, freedom of association) there was overwhelming consensus: between 92 percent and 95 percent of respondents answered that these elements "exactly" or "very nearly" described what they thought of as democracy.

40 Note that, especially in the context of Eastern European countries whose constituent elements agitate for independence-as in the case of Ukraine-defense of territorial integrity is not the same thing as defense of one's national borders. The latter is suggestive of defense of the country from outside attack, while the former, which was used in this study, suggests defense of the country from dissolution into its constituent political elements. 
In order to gauge nationalist sentiment, Ukrainians were asked how much they themselves felt that they had in common with Ukrainian nationalists. ${ }^{41}$ Regarding citizenship, Ukrainians were asked whether citizenship should be restricted to those who had lived in Ukraine for ten years; ${ }^{42}$ whether people who cannot speak Ukrainian (that is, Russians) have the right to be citizens; whether "more than anything else" Ukraine is the homeland of ethnic Ukrainians; whether Ukraine should be a place in which the ideas of everyone, including minorities, are welcome; and whether anyone who lives in Ukraine is a Ukrainian. The latter two are indicators of the kind of inclusivist view of the nation which liberals should express, and the first is an indicator of the kind of exclusivist view which liberals should not express.

The remaining questions-whether non-native speakers should be allowed to be citizens, and whether Ukraine should be the homeland of ethnic Ukrainians-are in fact ideal examples of the kinds of attitudes that characterize integral nationalists. Accordingly, I add them, along with a third variable which gauges the extent to which respondents believe the unity of Ukraine to be more important than the needs of individual regions, to form a measure of integral nationalism. This measure will be useful, both as a control variable and substantively, in the analyses that follow.

Unfortunately, comparable data from the Russian surveys are not available, as the same questions were not asked. One question in particular, however, can be used to assess the hypotheses regarding liberals and nationalism: respondents were asked whether Russia should follow the path of other industrialized countries or seek its own, uniquely Russian path. ${ }^{43}$ Unfortunately, this question is not directly comparable to the one asked in the Ukrainian survey, which introduces considerable uncertainty into the analysis. I mitigate this problem by examining similar questions which are comparable (in fact, identical) across republics in the section on "Generalizeability," below.

It was also necessary to insert some variables as controls in the analysis because of their potentially confounding effects. Sociodemographic characteristics-in particular, sex, age, and level of education-are often significant predictors of liberal attitudes. Given that this is the case, if these characteristics are also significantly associated with the dependent variables in these analyses (as they often are), omitting them would misattribute their influence to liberalism. They are not included in the hypotheses largely because, although their effects may be considerable, they are not plausible explanations for the democratic peace. Their inclusion is intended solely to ensure that liberalism's effects are not artificially inflated. ${ }^{44}$

\footnotetext{
41 This is a particularly difficult test in that the Ukrainian word for "nationalism" contains more radical and militant connotations than does its English counterpart (Kasianov, 1996).

42 Ukrainian law-dating from October 8, 1991—stipulated that citizenship was restricted to those who had been permanent residents of Ukraine for five or more years; therefore, the respondents would have been advocating a more restrictive citizenship policy than the one that existed at the time. See Barrington (1995:ch. 3).

43 I owe a considerable debt of gratitude to Ben Goldsmith for his thinking regarding this survey item.

${ }^{44}$ Sex is coded as $1=$ male, 2 = female. Age is included as the last two digits of respondent's year of birth (no respondents were born before 1900; the oldest was born in 1902). Education is coded on a 1-8 scale, where 1 signifies no formal education and 8 signifies postgraduate education. On the whole, the control variables showed few patterns of interest, and their inclusion in the tables more than doubled the amount of space taken up while distracting from the main substantive findings. For these reasons the coefficients are not reported, but the reader should rest assured that they were included in the analyses.
} 


\section{Empirical Results}

\section{Democratic Structure}

The analysis was carried out using an ordered probit model, which was appropriate given the ordinal nature of the dependent variables. ${ }^{45}$ The results are striking.

First of all, there is quite a bit of evidence to support structural theorists' assertion that the people are less warlike than are their leaders. Model I in Table 1 from the 1995 and 1993 surveys suggest that Russian decision makers have a somewhat more pessimistic view of Russia's relations with other countries than do her citizens. The findings are significant but not robust: ${ }^{46}$ coefficients for four of the seven countries are statistically significant in the 1993 survey, and coefficients for only two of the seven are significant in the 1995 survey.

There is a plausible argument to be made that the composition of the elite sample biases the empirical results—in particular, that including the military but excluding economic and academic elites (many of whom have some input into foreign policy decisions) makes the elite appear more intransigent than they really are. To test this possibility I re-estimated the model and included all elites surveyed. The results are reproduced as Model II, Table 1, for both the 1993 and 1995 Russia surveys. The coefficients for liberalism and perception of democracy showed no change in sign and only trivial changes in magnitude. As for the coefficients for elite status, most point and range estimates from the 1993 survey changed only minimally. In the 1995 survey, some more noticeable changes took place. The larger set of elites was notably more friendly toward Georgia, the United States, Germany, and China than were political and military leaders; on the whole relations with the latter two were even seen in a more positive light by elites than by the citizenry. The coefficients for Estonia and Poland, on the other hand, were considerably more negative for elites than for leaders.

Finally, it is possible that Russian leaders are more or less liberal than the mass public, ${ }^{47}$ and that as a result the coefficients for leadership status reflect something substantively different from that which interests us: we might be more interested in the relative bellicosity of leaders than in the effect of leadership status when liberalism has been controlled for. Accordingly, I estimated a third model (Model III, Table 1) in which the liberalism/perceptions of democracy variables were intentionally omitted. ${ }^{48}$ In both surveys the results largely remained stable; the 1995 survey saw no change in the pattern of significance, though leaders in the 1993 survey did perceive relations with six out of seven countries to be significantly more hostile than did citizens once the liberalism variable was dropped (as opposed to four of seven when the variable was included).

More support, though less robust, comes from Model I of Table 2. In the 1995 survey, Russian leaders did display significantly greater willingness than the public to use force to defend the territorial integrity of Russia and to defend the interests

${ }^{45}$ For technical details see McKelvey and Zavoina (1976); for a more comprehensive overview see Aldrich and Nelson (1984).

${ }^{46}$ By "robustness" I mean to denote relationships that hold consistently across countries (in Table 1) or scenarios (in Table 2).

47 They are, in fact, significantly more liberal, but only barely so.

48 Of course, omission of relevant independent variables which are correlated with other independent variables introduces bias into the coefficients of included variables, but in this case the argument suggests that the simple bivariate relationship, absent controls, is of greater interest. Simply put, the constraint argument hinges on the leaders being more bellicose than the citizenry; if we were to introduce some set of independent variables to control for the factors that make leaders more bellicose and thereby reduce the coefficient to zero, it would only mask the most relevant finding - that leaders are more bellicose than the citizenry. 
TABle 1. Perceptions of Friendly Relations

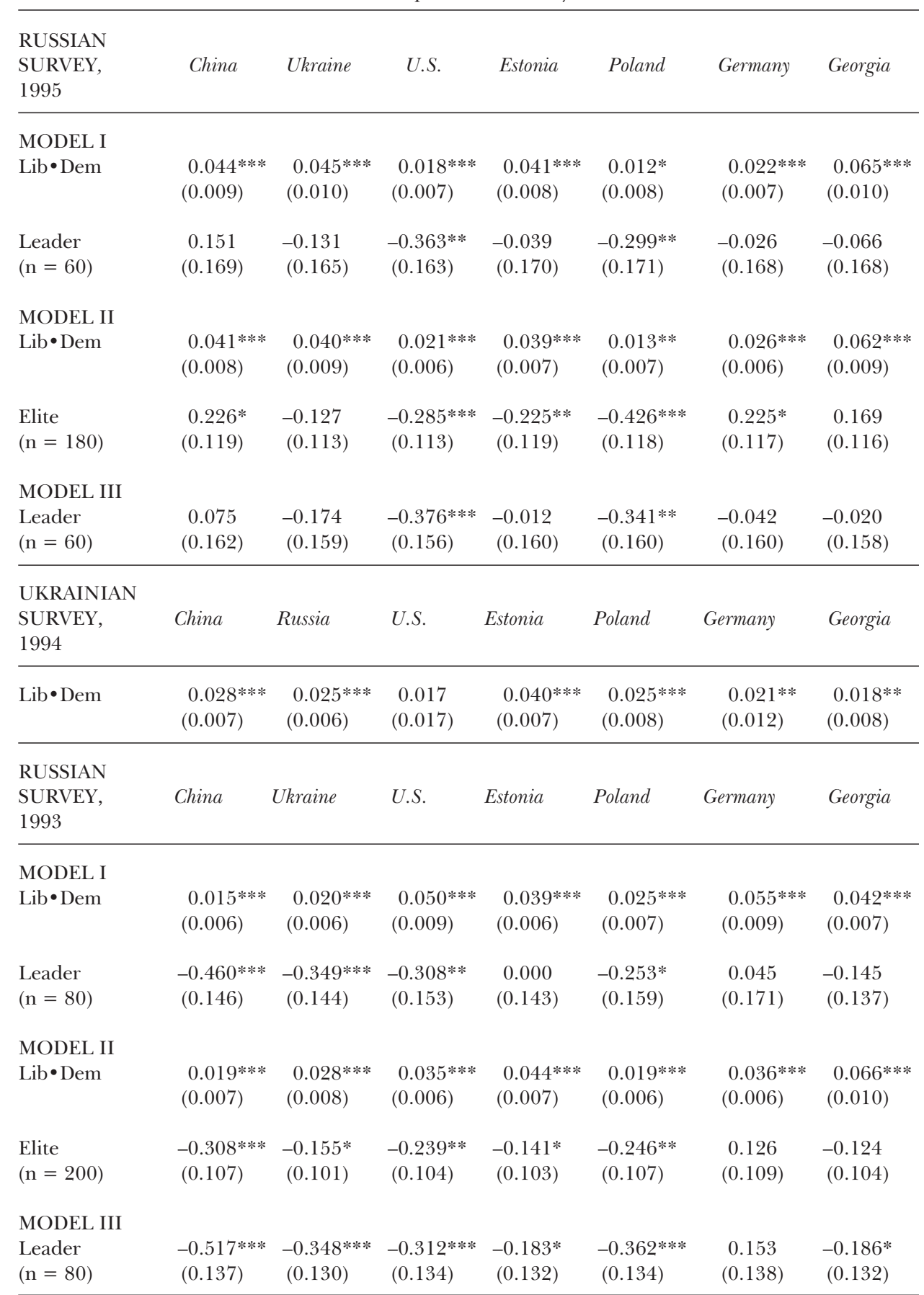

Numbers are probit coefficients; numbers in parentheses are standard errors.

Tests of significance are one-tailed unless sign of coefficient is in unexpected direction.

*significant at the .10 level; **significant at the .05 level; ***significant at the .01 level 
TABle 2. Advocacy of Use of Force

\begin{tabular}{|c|c|c|c|c|c|c|c|}
\hline Variable: & $\begin{array}{l}\text { Defend } \\
\text { territor'l } \\
\text { integrity }\end{array}$ & $\begin{array}{l}\text { Defend } \\
\text { economic } \\
\text { interests }\end{array}$ & $\begin{array}{l}\text { Defend } \\
\text { interests } \\
\text { of Russians } \\
\text { in xUSSR }\end{array}$ & $\begin{array}{c}\text { Defend } \\
\text { interests } \\
\text { of Russians } \\
\text { elsewhere }\end{array}$ & $\begin{array}{c}\text { Defend } \\
\text { interests } \\
\text { of Russian } \\
\text { state }\end{array}$ & $\begin{array}{c}\text { Defend } \\
\text { security of } \\
\text { our friends } \\
\text { abroad }\end{array}$ & $\begin{array}{c}\text { Get Russia } \\
\text { out of } \\
\text { current } \\
\text { crisis }\end{array}$ \\
\hline \multicolumn{8}{|l|}{$\begin{array}{l}\text { RUSSIAN } \\
\text { SURVEY, } \\
1995\end{array}$} \\
\hline \multicolumn{8}{|l|}{ MODEL I } \\
\hline Liberal & $\begin{array}{c}-0.018 \\
(0.032)\end{array}$ & $\begin{array}{c}-0.010 \\
(0.027)\end{array}$ & $\begin{array}{c}-0.036^{*} \\
(0.028)\end{array}$ & $\begin{array}{c}-0.022 \\
(0.032)\end{array}$ & $\begin{array}{c}-0.033 \\
(0.032)\end{array}$ & $\begin{array}{c}-0.033 \\
(0.034)\end{array}$ & $\begin{array}{c}-0.083 * * * \\
(0.031)\end{array}$ \\
\hline $\begin{array}{l}\text { Leader } \\
(\mathrm{n}=60)\end{array}$ & $\begin{array}{l}0.707 * * * \\
(0.296)\end{array}$ & $\begin{array}{c}-0.064 \\
(0.191)\end{array}$ & $\begin{array}{l}0.425^{* *} \\
(0.195)\end{array}$ & $\begin{array}{c}0.157 \\
(0.218)\end{array}$ & $\begin{array}{c}0.250 \\
(0.240)\end{array}$ & $\begin{array}{c}0.230 \\
(0.228)\end{array}$ & $\begin{array}{c}-0.378 \\
(0.238)\end{array}$ \\
\hline MODEL II & & & & & & & \\
\hline Liberal & $\begin{array}{c}-0.034 \\
(0.030)\end{array}$ & $\begin{array}{c}-0.009 \\
(0.025)\end{array}$ & $\begin{array}{c}0.031 \\
(0.025)\end{array}$ & $\begin{array}{c}-0.004 \\
(0.029)\end{array}$ & $\begin{array}{c}-0.034 \\
(0.030)\end{array}$ & $\begin{array}{c}-0.049 * \\
(0.031)\end{array}$ & $\begin{array}{c}-0.098 * * * \\
(0.030)\end{array}$ \\
\hline $\begin{array}{l}\text { Elite } \\
(n=180)\end{array}$ & $\begin{array}{l}0.486 \text { *** } \\
(0.176)\end{array}$ & $\begin{array}{c}-0.064 \\
(0.132)\end{array}$ & $\begin{array}{c}-0.239 * \\
(0.135)\end{array}$ & $\begin{array}{c}0.035 \\
(0.154)\end{array}$ & $\begin{array}{c}0.219 \\
(0.162)\end{array}$ & $\begin{array}{c}0.212^{*} \\
(0.161)\end{array}$ & $\begin{array}{c}-0.529 * * * \\
(0.169)\end{array}$ \\
\hline $\begin{array}{l}\text { MODEL III } \\
\text { Leader } \\
(\mathrm{n}=60)\end{array}$ & $\begin{array}{l}0.566^{* *} \\
(0.254)\end{array}$ & $\begin{array}{c}-0.049 \\
(0.170)\end{array}$ & $\begin{array}{c}-0.346 * * \\
(0.172)\end{array}$ & $\begin{array}{c}0.144 \\
(0.195)\end{array}$ & $\begin{array}{c}0.169 \\
(0.212)\end{array}$ & $\begin{array}{c}0.188 \\
(0.202)\end{array}$ & $\begin{array}{c}-0.424 * \\
(0.218)\end{array}$ \\
\hline $\begin{array}{l}\text { UKRAINIAN } \\
\text { SURVEY, } \\
1994\end{array}$ & $\begin{array}{l}\text { Defend } \\
\text { territor'l } \\
\text { integrity }\end{array}$ & $\begin{array}{l}\text { Defend } \\
\text { economic } \\
\text { interests }\end{array}$ & $\begin{array}{c}\text { Defend } \\
\text { interests } \\
\text { of } \\
\text { Ukrainians } \\
\text { in xUSSR }\end{array}$ & $\begin{array}{c}\text { Defend } \\
\text { interests } \\
\text { of } \\
\text { Ukrainians } \\
\text { elsewhere }\end{array}$ & $\begin{array}{l}\text { Achieve } \\
\text { national } \\
\text { security }\end{array}$ & $\begin{array}{l}\text { Resolve } \\
\text { conflicts } \\
\text { elsewhere }\end{array}$ & $\begin{array}{c}\text { Get Ukraine } \\
\text { out of } \\
\text { current } \\
\text { crisis }\end{array}$ \\
\hline Liberal & $\begin{array}{c}0.027 \\
(0.030)\end{array}$ & $\begin{array}{c}-0.008 \\
(0.029)\end{array}$ & $\begin{array}{l}0.085^{* *} \\
(0.035)\end{array}$ & $\begin{array}{l}0.082 * * \\
(0.039)\end{array}$ & $\begin{array}{c}0.036 \\
(0.027)\end{array}$ & $\begin{array}{l}0.120 * * * \\
(0.034)\end{array}$ & $\begin{array}{c}0.045 \\
(0.035)\end{array}$ \\
\hline
\end{tabular}

Numbers are probit coefficients; numbers in parentheses are standard errors.

Tests of significance are one-tailed unless sign of coefficient is in unexpected direction.

*significant at the .10 level; **significant at the .05 level; ***significant at the .01 level

of Russians in the former Soviet Union. On other issues responses were mixed; three out of the remaining five coefficients are in the expected direction, though none is statistically significant, and two are not.

In Model II of Table 2 I again contrast these findings to the results of a model in which all elites are included, and again the results are weakened-in five of seven cases the coefficient drops, indicating lessened belief in the legitimacy of the use of force. In two cases elites, taken as a whole, are actually significantly less supportive of the use of force than are citizens.

Finally, I again intentionally omit liberalism from the equation, and the magnitude of the coefficients drops across the board—evidence that strongly suggests that Russian leaders' liberalism tempers their views toward the use of force. In one case, defense of the interests of Russians in the former USSR, the coefficient changes from negative and significant to positive and significant once we cease to control for liberalism. 
What can we conclude from these results? First of all, there is considerable evidence to support the structuralists' point of view, though this evidence is not robust. Secondly, the evidence is strongest in the area of perceptions of hostile relations rather than beliefs about the legitimacy of the use of force. Finally, the extent to which the structural explanation is likely to hold water depends largely on the composition of the elite group which is responsible for the formulation of foreign policy. Evidence for the structural argument is strongest among political and military elites, and is especially strong when these groups are compared directly to the citizenry, without controls. In cases in which other elite groups hold some sway over foreign policy decisions, the relationship between decision maker status and both perceptions of hostility and beliefs about the legitimacy of the use of force is generally likely to be weaker and may even be reversed.

\section{Liberal Norms}

The results relating liberalism and perceptions of democracy to perceptions of peaceful relations conformed very strongly to the predictions of normative theories. In Russia, people who possessed liberal beliefs and who believed a foreign country to be democratic were significantly more likely to answer that relations with that country were friendly than they would otherwise have been. This relationship was strongly significant across all seven cases in both 1993 and 1995. In Ukraine, the same relationship held, though the results reached statistical significance in only six of the seven cases. (See Table 1.)

Furthermore, there is weaker support for the link between liberalism and avoidance of the use of force in the 1995 survey of Russia. In two cases-defense of the interests of Russians in the former Soviet Union and getting Russia out of its current crisis-liberals in Russia were less willing to use force than were illiberals. In all other cases the signs of the coefficients were as expected. (See Table 2.)

Finally, Table 2 demonstrates that liberals in Ukraine are often, though not always, more predisposed toward the use of force than are illiberals. ${ }^{49}$ Liberal Ukrainians are more likely to advocate the use of force in defense of Ukrainians in the former Soviet Union and elsewhere. Ukrainian liberals are also more willing to use force to resolve conflicts elsewhere-given the international activities of Ukraine at the time of the survey, this item probably measures more than anything else support for Ukrainian involvement in U.N. peacekeeping efforts in Bosnia, although there is certainly considerable ambiguity in the question. ${ }^{50}$ On the whole,

\footnotetext{
49 The fact that, as mentioned above, liberalism's implications for resolving conflicts are not entirely determinate is the reason for my use of two-tailed, rather than one-tailed, tests for significance in Table 2, though all significant cases are significant at the 0.05 level or greater regardless of which is used.

${ }^{50}$ The survey was carried out between April 11 and April 25, 1994. On April 13, 1994 it was announced that Ukrainian peacekeepers - who had been present in Bosnia since 1992—would be sent to defend Gorazde, which was under Serb attack. (The deployment was subsequently deferred, but not until three days after the last respondent had been interviewed.) It therefore seems likely that the bulk of the respondents had recently been exposed to news of Ukrainian peacekeeping efforts in Bosnia. To determine whether or not the new deployment had had an effect on liberal attitudes toward the use of force to resolve conflicts elsewhere, I partitioned the sample into two groups-those who had been interviewed before the announcement $(\mathrm{n}=382)$ and those who had been interviewed afterward $(\mathrm{n}=821)$-and determined that, although there was a slight increase in the slope coefficient for liberalism after the announcement was made, it was very probably $(\mathrm{p}=0.79)$ the product of random variation rather than of any systematic change in attitudes. There was virtually no difference in overall evaluations of the legitimacy of the use of force to resolve external conflicts between the pre-announcement and the post-announcement group. Given the prominence of the conflict in Bosnia and of Ukrainian involvement in it (mortar fire had hit Ukrainian peacekeepers' barracks in August of 1992, a Ukrainian had been killed in Sarajevo in April of 1993, and a Ukrainian colonel had been named U.N. commander in Sarajevo in early November of 1993), it seems likely that Ukrainian news stations were already running considerable coverage of the crisis, and that as a result the deployment had little effect on Ukrainian public opinion.
} 
these findings are far more consistent with the liberal nationalism argument which I have put forth than they are with the prevailing image of peaceful liberal norms of conflict resolution. 51

\section{Liberal Nationalism}

As Table 3 shows, there are indeed significant associations between liberalism and inclusivist attitudes toward citizenship. ${ }^{52}$ These associations suggest, first of all, that liberals are more likely to define Ukrainian citizenship in an inclusivist fashion. The Ukrainian state they envision is one that is open to all, regardless of the amount of time spent in Ukraine, and one that incorporates the opinions of minorities rather than attempting to force them to assimilate.

The results from the fifth and sixth columns of Table 3 represent significant support for the proposition that liberals are more likely to identify themselves as nationalists. Again, this is perhaps the most crucial test for the proposition that the liberalism encountered herein is of a national, rather than a universal, sort. In the sixth column I include a measure of integral nationalism, defined above, to determine whether or not the relationship between liberalism and nationalism holds once this variable is included. Two points are immediately apparent. The first is that integralism - which, like liberalism, is measured on a 10-point scale-is also very strongly associated with self-identification as a nationalist. The second is that the coefficient for liberalism is virtually unchanged when the measure of integralism is introduced, though the standard error has increased somewhat. Taken together, these facts suggest that two very distinct forms of nationalism, liberal and integral, are present in Ukraine.

As Russia's uniqueness is a centerpiece of Russia's (or any other country's) nationalist creed, and as I have posited that Russian liberalism-unlike that of the

TABLE 3. Liberal Views of Citizenship and Nationalism

\begin{tabular}{|c|c|c|c|c|c|c|}
\hline & \multicolumn{5}{|c|}{ UKRAINE 1994} & \multirow{2}{*}{$\begin{array}{c}\text { RUSSIA } 1995 \\
\text { Russia } \\
\text { should } \\
\text { follow } \\
\text { own path }\end{array}$} \\
\hline & $\begin{array}{l}\text { Must live in } \\
\text { Ukr. } 10 \\
\text { years to be } \\
\text { citizen }\end{array}$ & $\begin{array}{l}\text { All ideas } \\
\text { incl. those of } \\
\text { minorities } \\
\text { welcome }\end{array}$ & $\begin{array}{l}\text { All living } \\
\text { in Ukraine } \\
\text { are } \\
\text { Ukrainians }\end{array}$ & $\begin{array}{l}\text { Self-ID: } \\
\text { Ukrainian } \\
\text { nat'list }\end{array}$ & $\begin{array}{l}\text { Self-ID: } \\
\text { Ukrainian } \\
\text { nat'list }\end{array}$ & \\
\hline Liberal & $\begin{array}{l}-0.037 * * \\
(0.023)\end{array}$ & $\begin{array}{l}0.076 * * * \\
(0.025)\end{array}$ & $\begin{array}{l}0.043 * * \\
(0.025)\end{array}$ & $\begin{array}{l}0.052 * * \\
(0.026)\end{array}$ & $\begin{array}{l}0.049 * * \\
(0.029)\end{array}$ & $\begin{array}{l}-0.059 * * \\
(0.026)\end{array}$ \\
\hline Integral & - & - & - & - & $\begin{array}{l}0.264 * * * \\
(0.023)\end{array}$ & $\mathrm{n} / \mathrm{a}$ \\
\hline
\end{tabular}

Numbers are probit coefficients; numbers in parentheses are standard errors.

Tests of significance are one-tailed.

**significant at the .05 level; ***significant at the .01 level

51 One of the keys to interpreting these results is understanding which concepts are evoked when respondents construct hypothetical opponents. In particular, liberals may unconsciously construct nondemocratic opponents. The only observation I can offer in support of the assumption that this is not the case is that respondents are just as likely (if not more likely) to construct an answer in terms of likely opponents, and many of these (Germany, Poland, Russia) are widely believed to be relatively democratic.

52 The same control variables were included as in the previous analyses, for the same reason-to ensure that the effects of liberalism were not overestimated—as well as to ensure comparability. 
other republics-is of a more internationalist (and particularly, Western) sort, we should find that Russian liberals are less likely than illiberals to express nationalist sentiments, as measured by agreement with the item regarding whether or not Russia should follow its own path. As the last column of Table 3 demonstrates, this is exactly the case.

\section{Substantive Impact}

Statistical significance, of course, is not the same thing as substantive significance. A few examples should suffice to illustrate the extent to which the coefficients are substantively significant. Holding all other variables at their mean values, Russian leaders in the 1995 survey were less likely by 15 percent ( 32 percent vs. 47 percent) than citizens to respond that the United States was either "friendly" or "very friendly." They were more likely by 13 percent (95 percent vs. 82 percent) to respond that the use of force was legitimate in order to defend the country's territorial integrity. They were also less likely by 9 percent (12 percent vs. 21 percent) than citizens to respond that the use of force would be legitimate to get Russia out of its current crisis.

As to liberalism, perceptions of democracy, and perceptions of good relations, as expected the effect of the two independent variables was strongest when both were present. Among the citizenry, illiberals who thought the U.S. to be relatively undemocratic had an estimated probability of 37 percent of responding that the U.S. was either "friendly" or "very friendly." Illiberals who thought the U.S. to be democratic had an estimated probability of only 38 percent of giving one of those two answers. Liberals who thought the U.S. to be relatively undemocratic had an estimated probability of 43 percent of giving one of those two answers. Liberals who thought the U.S. to be relatively democratic, however, were much more likely-57 percent - to perceive relations with the U.S. to be friendly or very friendly than were any of the previous categories.

In order to gauge the magnitude of the positive effects of liberalism on advocacy of the use of force in Ukraine, I have calculated and graphed marginal probabilities of advocating the use of force at each point on the 10-point liberalism scale, keeping all other variables at their mean values (Figure 1). The results show clearly that the effects of liberalism are significant substantively as well as statistically. Moving from extreme illiberalism to extreme liberalism roughly tripled the respondent's probability of answering that the use of force in defense of the interests of Ukrainians in the former republics and elsewhere is legitimate and quintupled the respondent's probability of answering that the use of force to resolve conflicts elsewhere is legitimate. 53

The relationships between liberalism and nationalism are represented graphically in Figure 2. Again, the results are substantively as well as statistically significant. Moving from extreme illiberalism to extreme liberalism almost exactly doubles the probability that a Ukrainian will respond that he or she has "some" or "a great deal" (the two most positive of the four responses) in common with Ukrainian nationalists, from 12 percent to 24 percent. In Russia, on the other hand, moving from extreme illiberalism to extreme liberalism decreases the probability that a respondent will

\footnotetext{
53 One plausible interpretation of the data would be that extreme illiberals are relatively isolationist. I believe there to be considerable validity to this interpretation. It in no way refutes the finding, however; illiberal isolationism itself calls into question the relative pacificity of liberals.
} 


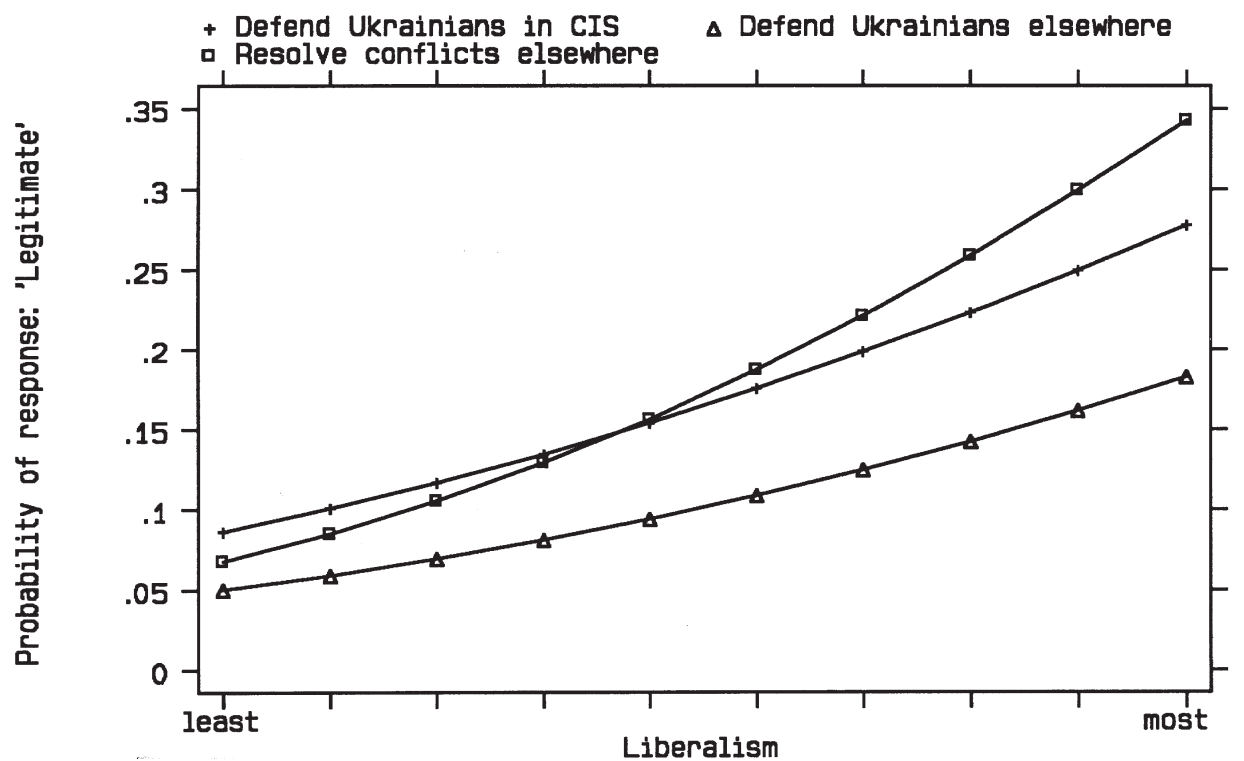

FIG 1. Liberalism and the legitimacy of the use of force.

answer that "Russia should seek its own course" by about a fifth, from 78 percent to 60 percent. ${ }^{54}$

The fact that different questions are used to measure nationalist sentiment is, of course, problematic, though it could be argued that the question in the Russian survey is better suited to the Russian context than the question in the Ukrainian survey would have been. In order to permit some sort of comparison, therefore, I have analyzed the results of a previous survey which is unique in that it both asks questions which are very similar to those utilized in the above analyses and spans multiple republics. The results are presented in the next section.

\section{Generalizeability}

One final question is that of generalizeability: how widespread is the relationship between liberalism and nationalism? Fortunately, Gibson and Duch (1990) conducted a survey in nine Soviet republics which contains items that might be of use in answering this question. ${ }^{55}$ I was able to reconstruct something very close to the liberalism variable used above, ${ }^{56}$ and another question in the survey gauged respondents' attitudes toward nationalists. In general, if I am correct about the prevalence of liberal nationalism in the Soviet successor states, we should find that the relationship between liberalism and nationalism is negative in Russia and positive in the other successor states. We should also find that the relationship between liberalism and nationalism is strongest in those states that were most active

54 The differences in the levels of support for these two dependent variables is striking but understandable; the word "nationalist," in Russian as in Ukrainian, carries strong negative connotations, and Russian dissatisfaction with reform in late 1995 made the alternative to Russia's seeking its own path-following the path of developed Western countries-largely unappealing.

55 Unfortunately only eight could be used, as there were too few Estonian respondents to permit analysis.

56 Three questions in the Gibson and Duch survey neatly paralleled the questions used to form the liberalism variable in the CPS surveys, although the wording was not the same; see the Appendix for details. 


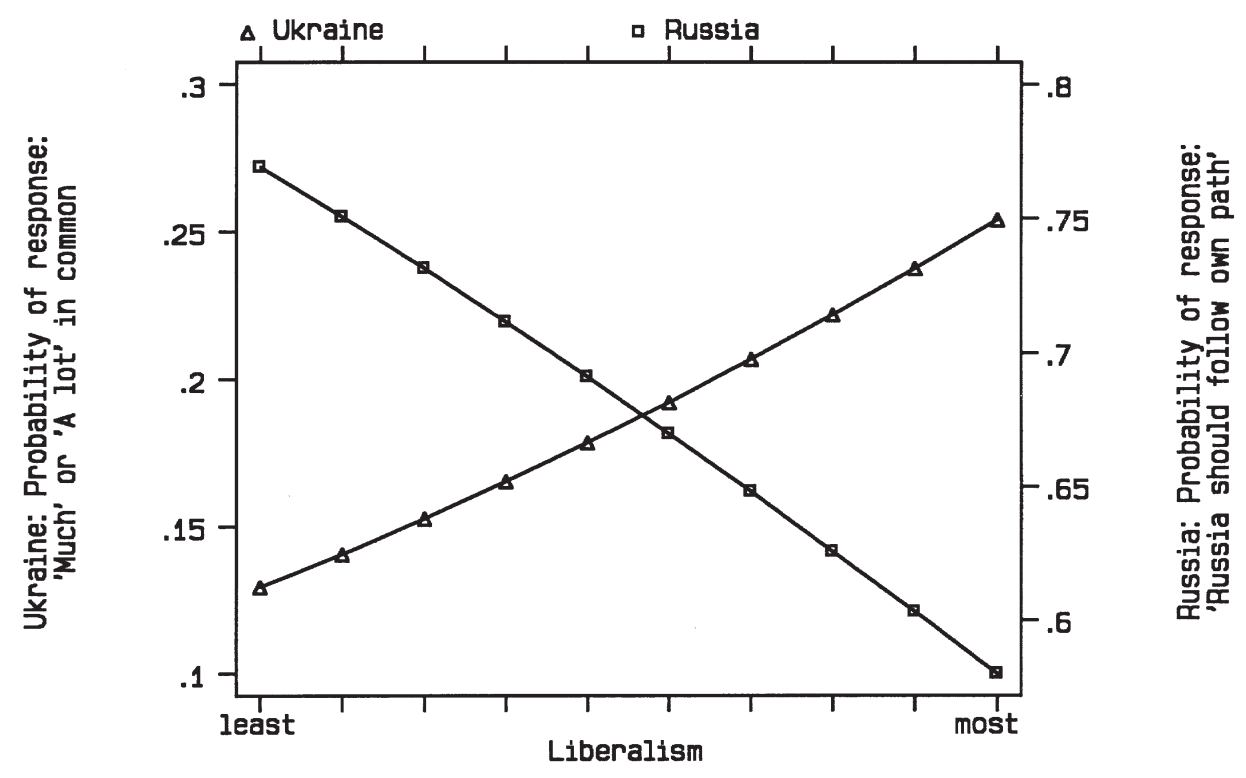

FIG 2. Liberalism and nationalism.

in their pursuit of independence-in particular, in the Baltic states-and weakest in Russia itself. The results are reproduced in Table 4, in order of the magnitude of the coefficients, and conform roughly to expectations, though the small number of respondents in most republics makes interpretation uncertain. The relationship between liberalism and attitudes toward nationalists is positive in all eight republics, though it reaches statistical significance in only three. The largest coefficients are to be found in the Baltic states, Georgia, and Ukraine (though the coefficient in Armenia is surprisingly large as well). The coefficient in Russia, by contrast, is minuscule; although it is not negative, given the ratio of the coefficient to its standard error the population parameter is about as likely to be negative as positive.

In short, these results suggest that the affinity between liberalism and nationalism is widespread in the successor states. It is stronger, as expected, in those states in which the two ideologies were more closely united in their pursuit of independence.

\section{Conclusion}

The goal of this article is to test the applicability of democratic peace arguments to the Soviet successor states, which was called into question because of the alliance between liberalism and nationalism characteristic of newly independent states. The findings suggest the following:

1. Liberal nationalism seems to be fairly widespread in the (non-Russian) former republics of the Soviet Union. Available evidence strongly suggests that this form of liberalism is not particularly pacifistic and in fact seems to predispose its adherents toward the use of force, especially in the name of national autonomy. Accordingly, the spread of this particular form of liberalism may hurt rather than help the prospects for peace. Where liberalism and nationalism find no common ground, as in Russia, however, liberalism does seem to play a pacifying role. 
TABLE 4. Relationship of Liberalism to Attitudes Toward Nationalism in Eight Soviet Republics, 1990

\begin{tabular}{lc}
\hline Liberalism in ... & Attitude toward nationalists \\
\hline Latvia & $\left(0.1954^{*}\right.$ \\
& $0.264^{* *}$ \\
Lithuania & $(0.106)$ \\
& 0.132 \\
Armenia & $(0.104)$ \\
& 0.119 \\
Georgia & $(0.100)$ \\
& $0.074^{* *}$ \\
Ukraine & $(0.029)$ \\
& 0.051 \\
Moldavia & $(0.126)$ \\
(Moldova) & 0.019 \\
Belorussia & $(0.071)$ \\
(Belarus) & 0.004 \\
Russia & $(0.020)$ \\
&
\end{tabular}

Source: Gibson and Duch 1990 survey (ICPSR 6099). Valid Ns are from top, 16, 25, 39, 20, 361, 25, 70, 843; Estonia was dropped from analysis due to an insufficient number of respondents.

Numbers are probit coefficients; numbers in parentheses are standard errors.

Tests of significance are two-tailed.

*significant at the .10 level; **significant at the .05 level

2. The results most consistently support the contention that the combination of liberalism - whether or not of the nationalist variety - and perceptions of democracy improves relations among countries by lowering perceptions of hostility.

3. The extent to which national leaders possess more bellicose attitudes or more negative images of potential opponents depends to a large extent on who those leaders are. If the people in control of foreign policy are political and military elites, there is considerable evidence to demonstrate that their images of potential opponents are more negative than those of the citizenry and some to suggest that they are more willing to advocate the use of force. To the extent that a more diverse group of elites has influence over policy, however, these generalizations are less likely to hold.

4. The findings support the conclusion that democratization, if widely implemented and recognized, may improve the prospects for peace among the Soviet successor states by improving relations among them. The evidence presented here supports such a possibility for both structural and normative reasons. ${ }^{57}$ If, however, peace obtains in the face of persistent disagreements over issues of autonomy and

\footnotetext{
${ }^{57}$ Remember, however, that I make no claims regarding the ability of political institutions to constrain leaders in the former Soviet Union, which is a necessary component of the structural argument. In particular, if Mansfield and Snyder (1995) are correct, dysfunctional institutions may render the benefits of constraint null and void.
} 
the rights of national minorities, it may do so despite liberal attitudes toward the use of force rather than because of them.

These points suggest that peace among democracies in the region is sustainable but will be especially vulnerable to national issues and to the effects of narrow political institutions, both on foreign policy and foreign perceptions. ${ }^{58}$ The former is especially likely to provoke liberal nationalists, while the latter diminishes perceptions of democracy abroad and eschews the moderating influence of a broader policy-making community. Accordingly, the most promising scenario for regional peace would involve both a broad distribution of decision-making power among elites (both to moderate the perceptions and attitudes of the leadership and to foster the image of a democratic state abroad) and vigilance against any hint of mistreatment of national minorities or infringements upon the autonomy of other states. 59

The results also suggest that democratic peace scholars have overlooked a critical aspect of liberal norms: liberalism is not monolithic, and the context in which it arises strongly influences its implications for peace.

\section{Appendix \\ Variables to Be Operationalized and Questions Used}

\section{Liberalism (R93, U94, R95)}

(To what extent do you agree or disagree with the following statements:)

"In any society there will always be a need to forbid the public expression of dangerous ideas." (-)

"The rights of the individual must be defended even if guilty people sometimes go free." (+)

"Competition among various political parties makes our political system stronger." (+)

\section{Liberalism (SSV90)}

(I am now going to read you a number of statements. Would you please indicate whether you agree strongly, agree, disagree, or disagree strongly:)

"Free speech is just not worth it if it means that we have to put up with the danger to society of extremist political views." (-)

"It is better to live in an orderly society than to allow people so much freedom that they become disruptive." (-)

"There is too much democracy in the Soviet Union today." (-)

Extent to which other states are believed to be democratic (R93, U94, R95)

"Please tell me for each country I mention if you think it is more democratic than, less democratic than, or about as democratic as (Russia/Ukraine)?"

\section{Friendly/hostile relations with other states (R93, U94, R95)}

"Please tell me for each one (of these countries) about its relations with (Russia/Ukraine). Is it very friendly, rather friendly, neutral, rather hostile, or very hostile toward (Russia/Ukraine)?”

\footnotetext{
58 For a detailed account of national minorities across the globe see Gurr (1993:326-63 and passim).

59 Current prospects for the former seem grim. The elites polled in the 1995 survey of Russia were also asked to rank various institutions and groups in terms of their influence over foreign policy, on a scale of 1 (none) to 7 (total). The President received a mean score of 6.2, while the Duma and the public received scores of 3.5 and 3.0, respectively. (The other contenders were the Ministry of Foreign Affairs (5.1), the Ministry of Defense (4.4), the biznes-elita (4.2), and regional leaders (3.3).) The distribution suggests that Russia's foreign policy will be heavily influenced by its President—and that it will be judged accordingly.
} 


\section{Legitimacy of use of force (U94)}

"Do you think it is legitimate to use military force to: (defend the territorial integrity of Ukraine; defend Ukrainian economic interests; defend the interests of Ukrainians living in other former republics of the USSR; defend the interests of Ukrainians elsewhere; achieve national security; contribute to the resolution of other conflicts; achieve conditions that would enable Ukraine to get out of its present crisis)" (Y/N)

\section{Legitimacy of use of force (R95)}

"Do you think it is legitimate to use military force to: (defend the territorial integrity of Russia; defend Russian economic interests; defend the interests of Russians living in other former republics of the USSR; defend the interests of Russians elsewhere; defend the interests of the Russian state; defend the security of our friends abroad; achieve conditions that would enable Russia to get out of its present crisis)" (Y/N)

\section{Attitudes about citizenship (U94)}

"People have different views about what it means to be a citizen of Ukraine. Here are some statements people have made about this. Please tell me whether you strongly agree, agree, disagree, or strongly disagree with each statement: a. No one should be a citizen of Ukraine, unless he or she has lived here for at least ten years. d. It is absolutely essential that Ukraine be a place where the ideas of everyone, including members of ethnic minorities, are welcome. e. Anyone who lives in Ukraine is a Ukrainian."

\section{Nationalism (U94)}

"Our society is made up of different groups of people. Any individual may have much in common with some of these groups and very little in common with other groups. On this card is a list of various social groups. For each of these groups, I would like to find out how much you have in common with their ideas, interests, and outlooks on different events: a great deal, some, very little, or nothing. . . . h. Ukrainian nationalists. $(+)$

\section{Nationalism (SSV90)}

"And now we'd like to ask you about your attitudes towards some groups of people. I am going to read you a list of some groups that are currently active in social and political life. Here is a card showing a scale from 1 to 11 . A " 1 " indicates that you DISLIKE the group very much; an "11" indicates that you LIKE the group very much. ... What is your attitude toward nationalists?" $(+)$

\section{Integral nationalism (U94)}

"People have different views about what it means to be a citizen of Ukraine. Here are some statements people have made about this. Please tell me whether you strongly agree, agree, disagree, or strongly disagree with each statement: b. A person who can not speak Ukrainian has no right to be a citizen of Ukraine. (+) c. More than anything else, Ukraine is the homeland of ethnic Ukrainians. (+)" "Here are several assertions about which there are various viewpoints. What is your opinion: do you fully agree with them, partially agree, partially disagree, or fully disagree? ...f. The unity of Ukraine is more important than the needs of individual regions. (+)"

$($ R93 $)=1993$ Russian survey, $($ U94 $)=1994$ Ukrainian survey, $($ R95 $)=1995$ Russian survey, $($ SSV90) $=1990$ Survey of Soviet Values (Gibson and Duch, 1990)

$(+)=$ positive response positively associated with indicator, $(-)=$ positive response negatively associated with indicator 


\section{References}

Aldrich, J. H., ANd F. D. Nelson (1984) Linear Probability, Logit, and Probit Models. Sage University Paper series on Quantitative Applications in the Social Sciences, 07-045. Beverly Hills and London: Sage.

Anderson, B. R. O'G. (1991) Imagined Communities: Reflections on the Origin and Spread of Nationalism, 2nd ed. New York: Verso.

Armstrong, J. A. (1990) Ukrainian Nationalism. Englewood, NJ: Ukrainian Academic Press.

BABST, D. (1964) Elective Governments-A Force for Peace. The Wisconsin Sociologist 3:9-14.

Barrington, L. (1995) To Exclude or Not to Exclude: Citizenship Policies in Newly Independent States. Ph.D. dissertation, University of Michigan.

Best, G. (1988) Editor's Introduction. In The Permanent Revolution: The French Revolution and Its Legacy, 1789-1989, edited by G. Best, pp. 1-15. London: Fontana Press.

BREMER, S. A. (1993) Democracy and Militarized Interstate Conflict, 1816-1965. International Interactions 18:231-249.

Breuilly, J. (1993) Nationalism and the State. Manchester, England: Manchester University Press.

Bueno de Mesquita, B., and D. Lalman (1992) War and Reason. New Haven, CT: Yale University Press.

Chan, S. (1984) Mirror, Mirror on the Wall . . . Are the Freer Countries More Pacific? Journal of Conflict Resolution 28:617-648.

Chan, S. (1993) Democracy and War: Some Thoughts on Future Research Agenda. International Interactions 18:205-213.

Dixon, W. (1994) Democracy and the Peaceful Settlement of International Conflict. American Political Science Review 88:14-32.

Doyle, M. (1983a) Kant, Liberal Legacies and Foreign Affairs. Part 1. Philosophy and Public Affairs 12:205-235.

Doyle, M. (1983b) Kant, Liberal Legacies and Foreign Affairs. Part 2. Philosophy and Public Affairs 12:323-353.

DunloP, J. B. (1983) The Faces of Contemporary Russian Nationalism. Princeton, NJ: Princeton University Press.

Ember, C. R., M. Ember, And B. Russett (1992) Peace Between Participatory Polities: A Cross-Cultural Test of the "Democracies Rarely Fight Each Other" Hypothesis. World Politics 44:573-599.

Farber, H. S., AND J. Gowa (1995) Polities and Peace. International Security 20:123-146.

Fukuyama, F. (1992) Comments on Nationalism and Democracy. Journal of Democracy 3:23-28.

Furtado, C., And A. Chandler, eds. (1992) Perestroika in the Soviet Republics: Documents on the National Question. Boulder, CO: Westview Press.

Gaubatz, K. T. (1991) Election Cycles and War. Journal of Conflict Resolution 35:212-244.

Gibson, J., AND R. Duch (1990) Survey of Soviet Values (ICPSR 6099). Ann Arbor, MI: Inter-University Consortium for Political and Social Research.

Gitelman, Z. (1992) "Ethnopolitics and the Future of the Former Soviet Union." In The Politics of Nationality and the Erosion of the USSR: Selected Papers from the Fourth World Congress for Soviet and East European Studies, edited by Z. Gitelman, pp. 1-25. New York: St. Martin's Press.

Guizot, F. (1852) History of the Origin of Representative Government in Europe (trans. A. R. Scoble). London: H. G. Bohn.

Gurr, T. R. (1993) Minorities at Risk: A Global View of Ethnopolitical Conflicts. Washington, DC: United States Institute of Peace Press.

Hayes, C. J. H. (1931) The Historical Evolution of Modern Nationalism. New York: Richard R. Smith.

Hermann, M. G., And C. W. Kegley, JR. (1995) Rethinking Democracy and International Peace: Perspectives from Political Psychology. International Studies Quarterly 39:511-533.

Hobsbawm, E. J. (1992) Nations and Nationalism Since 1780: Programme, Myth, Reality, 2nd ed. New York: Cambridge University Press.

Hochschild, J. L. (1986) Dimensions of Liberal Self-Satisfaction: Civil Liberties, Liberal Theory, and Elite-Mass Differences. Ethics 96:386-399.

Hoffmann, S. (1995) The Crisis of Liberal Internationalism. Foreign Policy 98:159-177.

Hopf, T. (1996) "Identity and Russian Foreign Policy." In The Sources of Russian Foreign Policy After the Cold War, edited by C. Wallander, pp. 147-172. Boulder, CO: Westview Press.

Hough, J. F., And M. Fainsod (1979) How the Soviet Union Is Governed. Cambridge, MA: Harvard University Press.

Howard, M. (1978) War and the Liberal Conscience. New Brunswick, NJ: Rutgers University Press.

Judt, T. (1994) "The New Old Nationalism." The New York Review of Books, May 26, 1994, pp. 44-51. 
KaISER, R. J. (1994) The Geography of Nationalism in Russia and the USSR. Princeton, NJ: Princeton University Press.

Kant, I. (1957) Perpetual Peace, edited and translated by L. W. Beck. Indianapolis, IN: Bobbs-Merrill.

Kasianov, H. (1996) Ukrainian Nationalism Revisited: New Analytical Approaches. Address, University of Michigan, 2/8/96.

Khasbulatov, R. (1993) The Struggle for Russia: Power and Change in the Democratic Revolution, edited by R. Sakwa. New York: Routledge.

Kiser, E., K. A. Drass, And W. Brustein (1995) Ruler Autonomy and War in Early Modern Western Europe. International Studies Quarterly 39:109-138.

Kissinger, H. (1966) Domestic Structure and Foreign Policy. Dadalus 95:503-529.

KoHn, H. (1944) The Idea of Nationalism: A Study in Its Origins and Background. New York: Macmillan.

Lakatos, I. (1970) “The Methodology of Scientific Research Programmes." In Criticism and the Growth of Knowledge, edited by I. Lakatos and A. Musgrave, pp. 91-195. Cambridge: Cambridge University Press.

Lake, D. (1992) Powerful Pacifists: Democratic States and War. American Political Science Review 86:24-37.

LaYne, C. (1994) Kant or Cant: The Myth of the Democratic Peace. International Security 19:5-49.

LENG, R. J. (1993) Reciprocating Influence Strategies in Interstate Crisis Bargaining. Journal of Conflict Resolution 37:3-41.

Levinson, S. (1995) Is Liberal Nationalism an Oxymoron? An Essay for Judith Shklar. Ethics 105:626-645.

Lilla, M. (1994) The Other Velvet Revolution: Continental Liberalism and Its Discontents. Dadalus 123:129-157.

Mansfield, E. D., And J. Snyder (1995) Democratization and the Danger of War. International Security 20:5-38.

MaOZ, Z., AND N. AbDOlali (1989) Regime Types and International Conflict. Journal of Conflict Resolution 33:3-35.

McFaul, M., and S. Markov (1993) The Troubled Birth of Russian Democracy: Parties, Personalities, and Programs. Stanford, CA: Hoover Institution Press.

McKelvey, R. D., ANd W. Zavoina (1976) A Statistical Model for the Analysis of Ordinal Level Dependent Variables. Journal of Mathematical Sociology 4:103-120.

Mearsheimer, J. J. (1990) Back to the Future: Instability in Europe After the Cold War. International Security 15:5-56.

Mendus, S. (1989) Toleration and the Limits of Liberalism. Hong Kong: Macmillan.

MiLl, J. S. (1958) Considerations on Representative Government. Indianapolis, IN: Library of Liberal Arts Press.

Montesquieu, C. De S., BARON de (1900) The Spirit of Laws (trans. T. Nugent). New York: Colonial Press.

Morgan, T. C. (1993) Democracy and War: Reflections on the Literature. International Interactions 18:197-203.

Morgan, T. C., ANd S. H. Campbell (1991) Domestic Structure, Decisional Constraints, and War: So Why Kant Democracies Fight? Journal of Conflict Resolution 35:187-211.

Neuberger, R. B. (1986) National Self-Determination in Postcolonial Africa. Boulder, CO: Lynne Rienner.

Nincic, M. (1992) Democracy and Foreign Policy: The Fallacy of Political Realism. New York: Columbia University Press.

Nodia, G. (1992) Nationalism and Democracy. Journal of Democracy 3:3-22.

Oneal, J. R., F. H. Oneal, Z. Maoz, and B. Russett (1996) The Liberal Peace: Interdependence, Democracy, and International Conflict. Journal of Peace Research 33:1-18.

Oren, I. (1995) The Subjectivity of the "Democratic" Peace. International Security 20:147-184.

RAY, J. L. (1993) Wars Between Democracies: Rare or Non-Existent? International Interactions 18:251-276.

Ray, J. L. (1995) Democracy and International Conflict: An Evaluation of the Democratic Peace Proposition. Columbia: University of South Carolina Press.

Riasanovisky, N. V. (1984) A History of Russia, 4th ed. New York: Oxford University Press.

Rousseau, D., C. GelPi, D. Reiter, AND P. K. Huth (1996) Assessing the Dyadic Nature of the Democratic Peace, 1918-1988. American Political Science Review 90:512-533.

RummeL, R. J. (1985) Libertarian Propositions on Violence Within and Between Nations. Journal of Conflict Resolution 27:419-455.

Russett, B. (1993) Grasping the Democratic Peace. Princeton, NJ: Princeton University Press.

RussetT, B. (1995) And Yet It Moves. International Security 19:164-175.

SAlvadoRI, M., ED. (1972) European Liberalism. New York: John Wiley \& Sons.

SARTORI, G. (1987) The Theory of Democracy Revisited. Chatham, NJ: Chatham House. 
Schmitт, C. (1985) The Crisis of Parliamentary Democracy. Cambridge, MA: MIT Press.

SCHUMPETER, J. (1955) Imperialism and Social Classes. Cleveland, OH: World.

Schwan, A. (1987) "German Liberalism and the National Question in the Nineteenth Century." In

Nation-Building in Central Europe, edited by H. Schulze, pp. 65-80. New York: Berg.

Shafer, B. C. (1972) Faces of Nationalism. New York: Harcourt Brace Jovanovich.

Sheehan, J. J. (1978) German Liberalism in the Nineteenth Century. Chicago: University of Chicago Press.

Small, M., AND J. D. Singer (1976) The War-Proneness of Democratic Regimes. Jerusalem Journal of International Relations 1:50-69.

Smith, A. D. (1991) National Identity. Las Vegas: University of Nevada Press.

SNYDER, J. (1990) Averting Anarchy in the New Europe. International Security 14:5-41.

SNYDER, J. (1993) "The New Nationalism: Realist Interpretations and Beyond." In The Domestic Bases of Grand Strategy, edited by R. Rosecrance and A. A. Stein, pp. 179-200. Ithaca, NY: Cornell University Press.

SNYDER, J. (1994) Russian Backwardness and the Future of Europe. Dadalus 123:179-201.

SPIRO, D. E. (1994) The Insignificance of the Liberal Peace. International Security 19:50-86.

SPIRO, D. E. (1995) And Yet It Squirms. International Security 19:177-180.

SpITZ, D. (1982) The Real World of Liberalism. Chicago: University of Chicago Press.

Stark, A. (1995) Adieu, Liberal Nationalism. The New York Times, November 2, v. 145, pp. A15(N), A27(L), col. 2.

Subtelny, O. (1994a) "Imperial Disintegration and Nation-State Formation: The Case of Ukraine." In National Identity and Ethnicity in Russia and the New States of Eurasia, edited by J. W. Blaney, pp. 184-195. Armonk, NY: M. E. Sharpe.

Subtelny, O. (1994b) Ukraine: A History. Buffalo, NY: University of Toronto Press.

TAmiR, Y. (1993) Liberal Nationalism. Princeton, NJ: Princeton University Press.

TocQueville, A. DE (1873) Democracy in America (trans. H. Reeve). Boston: J. Allyn.

Van Evera, S. (1990-91) Primed for Peace: Europe After the Cold War. International Security 15:7-57.

Waltz, K. N. (1959) Man, the State, and War. New York: Columbia University Press.

WeEDE, E. (1992) Some Simple Calculations on Democracy and War Involvement.Journal of Peace Research 29:377-384.

WiLlis, I. C. (1928) England's Holy War: A Study of English Liberal Idealism During the Great War. New York: Alfred A. Knopf.

Zimmerman, W. (1994) Markets, Democracy, and Russian Foreign Policy. Post-Soviet Affairs 10:103-126.

Zimmerman, W., and A. Stam (1994) Constrained Belief Systems, "Rational" Publics, and Post-Soviet Russian Foreign Policy. Paper presented at the Annual Meeting of the International Studies Association, Washington, D.C., March 29. 